\title{
Effect of Cholecystokinin-Octapeptide and Cerulein on Phasic and Tonic Components in Ovine Duodenum with Special Reference to the 'Minute Rhythm'
}

\author{
K. W. ROMAŃSKI \\ Department of Animal Physiology, Faculty of Veterinary Medicine, Wroclaw Agricultural University, \\ Wroclaw, Poland \\ Received December 6, 2005 \\ Accepted September 5, 2006
}

\begin{abstract}
Romański K. W.: Effect of Cholecystokinin-Octapeptide and Cerulein on Phasic and Tonic Components in Ovine Duodenum with Special Reference to the 'Minute Rhythm'. Acta Vet Brno 2007, 76: 17-25

Cholecystokinin (CCK) can affect phasic contractions and the minute rhythm (MR) in ovine duodenum but its effect on the tonic component remains unclear. Thus, the aim of this study was to assess whether the hormone exerts significant changes on phasic and tonic components of the duodenal motor activity and on phasic and tonic components of the duodenal MR. Mechanical and electrical activities of the duodenum were recorded in four sheep before and after slow intravenous cholecystokinin octapeptide (CCK-OP, doses 20, 200 and $2000 \mathrm{ng} / \mathrm{kg}$ b.w.) and cerulein (doses 1, 10 and $100 \mathrm{ng} / \mathrm{kg}$ b.w.) administration in the course of phase $2 \mathrm{~b}$ of the migrating motor complex. During 5-20-minute periods the area under contraction curve for phasic, tonic and total motor activity was measured for the whole curve and separately for the MR-related activity. It was found that both CCK peptides stimulate phasic and tonic components of the duodenal motor activity as well as both these components of the duodenal MR. The effect of CCK peptides on the tonic component was stronger than on the phasic component. These effects were similar in non-fasted and fasted animals. CCK-OP evoked slightly greater effect than cerulein. The effects of these CCK peptides on phasic and tonic components of the MR were similar. It is concluded that CCK-OP and cerulein stimulate both phasic and tonic components of the duodenal motor activity and phasic and tonic components related to the MR in sheep.
\end{abstract}

Ruminants, small bowel, myoelectrical and motor activity, cholecystokinin

The minute rhythm (MR) is an easily recognizable motility pattern in the small bowel of various animal species including sheep (Fleckenstein et al. 1982). Beside the migrating motor complex (MMC) and feeding pattern, it is one of the basic motility patterns and comprises one or even more consecutive contractions or spike bursts arriving cyclically, every around one-minute periods. This pattern occurs mainly during the longest MMC phase and migrates through the upper small bowel or exhibits a stationary character (Romański 2002). As it was stated before (Summers and Dusdieker 1981), migratory MR might have a propulsive character. However, the exact propulsive nature of MR has not been determined. Ordinary phasic contractions in the small bowel (except phase 3 of the MMC) are not particularly strong. When the substantial tonic component occurs in the small intestine (Malbert and Ruckebusch 1989) it can be assumed that this component strengthens the wall tension and its contraction force. Thus, it seems likely that MR can exhibit not only phasic but also tonic component and it may mean that the propulsive efficacy of the MR would be expected to be greater. It appears that cholecystokinin (CCK) is able to affect the small-intestinal MR also in sheep. This hormone exerts multiple physiological and pharmacological actions (Walsh 1994) and disturbances of its release and responsiveness accompany several motility disorders (Chua and Keeling 2006; Di Francesco et al. 2005; Jensen 2002). CCK is also active in ruminants and affects the gastrointestinal motility directly or indirectly and this action involves both central and 
peripheral mechanisms (Cottrell and Reynolds 1994; Harvatine and Allen 2005; Kania et al. 2006; Onaga et al. 1997; Romański 2004; Zavros and Shulkes 1997). CCK is known to evoke the long-lasting tonic contraction in the gallbladder (B ehar et al. 2006). The existence of its action of tonic contractions within the gastrointestinal tract in both in vivo and in vitro studies was also suggested (Coffin et al. 1999; Rakovska et al. 1986; Schang and Kelly 1981).

Therefore, our aim was: 1) to determine separately the phasic and tonic component of mechanical activity before and after CCK-OP and cerulein administration (mainly for comparison of their potencies) and 2) to establish whether the MR exhibits its tonic component and whether the CCK peptides can affect both phasic and tonic components of the MR in the duodenum, where the MR is most precisely identifable.

\section{Materials and Methods}

Four Polish Merino adult rams weighing 40 - $44 \mathrm{~kg}$ each were used. Animals were fasted $24 \mathrm{~h}$ before the surgery. Then, under premedication (Combelen, Bayer, $2.5 \mathrm{ml}$ intramuscularly and $2.5 \mathrm{ml}$ intravenously), general ( $25 \%$ of sterile ethyl alcohol $3.5 \mathrm{ml} / \mathrm{kg}$ of body weight intravenously) and local anesthesia (40 $\mathrm{ml}$ of $1 \%$ Polocainum hydrochloricum, Biowet), right lateral $10-12 \mathrm{~cm}$ laparotomy was performed. Four bipolar platinum electrodes embedded in teflon coat were attached at the serosal side to the duodenal bulb (one electrode, $6 \mathrm{~cm}$ distally to the pyloric ring), the duodenum (main duodenal electrode, $50 \mathrm{~cm}$ distally to the bulbar electrode) and two additional duodenal electrodes spaced 15 and $30 \mathrm{~cm}$ distally to the bulbar electrode, as well as the duodenal strain gauge force transducer (RB Products, Madison) sewn just near the main duodenal electrode, were sutured. Strain gauge force transducer was calibrated individually before surgery. Tissue reactivity in response to the insertion of electrodes was previously checked during three months and no inflammatory reactions were observed in histological preparations of tissue surrounding the electrodes (Romański and Kuryszko 1995). Electrodes and transducer marked wires were exteriorized onto the upper right lateral region, fixed over the skin and soldered to the plug. During the surgery no muscular, peritoneal, visceral or corneal reflexes were observed. Additional $10-20 \mathrm{ml}$ of $25 \%$ ethyl alcohol was given intravenously and/or up to $10 \mathrm{ml}$ of Polocainum hydrochloricum were administered locally when necessary. Just after the operation, $6-7 \mathrm{ml}$ of Biowetalgin (Biowet), 1.2 million I.U. of Penicillinum procainicum (Polfa) and $0.5 \mathrm{~g}$ of Streptomycinum (Polfa) were given intramuscularly. At least 10 days were allowed for post-surgical recovery before the onset of experimental period. During this period, drinking water was not limited and the rations of fodder were gradually increased within 3 - 5 days after the operation. Then, the animals were fed a complete standard amount of fodder, i.e. with good quality hay, $1 \mathrm{~kg}$ per animal per day and a standard grain mixture, $4-5 \mathrm{~g} / \mathrm{kg}$ of body weight per animal daily.

Experiments were performed in $48 \mathrm{~h}$ fasted and in non-fasted animals which were fed $20-24 \mathrm{~h}$ before the experiment; this latter group was called "non-fasted" animals. Drinking water was restricted solely during the recording session. The myoelectric and motor recordings were performed in all the animals throughout the experiments using the adapted multichannel electroencephalograph (Reega Duplex TR XVI, Alvar, Montreuil). Experiments lasted $3-4.5 \mathrm{~h}$ each. During control recording normal MMC and MR patterns were visually identified in the duodenum. These patterns were determined according to the criteria published elsewhere (Code and Marlett 1975; Dent et al. 1983; Fleckenstein et al. 1982; Romań ski 2002). While the MMC was considered as a four-part cycle, the MR was undertaken as the rhythmically arriving episodes of usually $1-4$ spike bursts in the duodeno-jejunum and exhibiting the frequency range $0.3-1.8 \mathrm{cpm}$ (cycles per minute) (Romań ski 2002). Initially, at least two normal consecutive phases $3 \mathrm{MMC}$ were recorded. Then $0.15 \mathrm{M} \mathrm{NaCl}$ at the rate of $5 \mathrm{ml}$ or CCK hormonal peptide was administered intravenously during $30 \mathrm{sec}$ through the indwelling jugular polyethylene cathether, introduced before the experiment, and the recording of the myoelectric activity was continued. This slow intravenous injection was initiated very carefully using plastic syringes and within first $5 \mathrm{sec}$ its rate became gradually maximal while five seconds before its termination, its rate gradually lowered. Two CCK analogues were used. Cerulein (Takus, Farmitalia Carlo Erba, Milan) was administered at the doses of 1,10 and $100 \mathrm{ng} / \mathrm{kg}$ of body weight and CCK-OP (Sincalide, Squibb Institute, Princeton) was given at the doses of 20, 200 and $2000 \mathrm{ng} / \mathrm{kg}$ of body weight. Each dose of CCK peptide was given during separate experiments in random order. Drugs and saline were injected during phase $2 \mathrm{~b}$ of the MMC. Two consecutive experiments with $\mathrm{CCK}$ administration were performed with at least 1,2 or 3-day interval depending on the magnitude of the dose. The total of 96 double experiments including control recordings without saline injection and CCK administration as well as eight experiments with saline injection were conducted.

In myoelectric recordings the MMC cycles and MR patterns were identified in the duodenum. In mechanical recordings the area of phasic and tonic contractions as well as the sum of all contraction areas (area under the curve, AUC) were calculated and summarized during control and post-CCK periods and expressed as $\mathrm{g} \cdot \mathrm{sec}$. These periods lasted $5 \mathrm{~min}$ for the smallest dose of CCK peptide, $10 \mathrm{~min}$ for moderate dose and $20 \mathrm{~min}$ for the high dose and were recalculated for standard one-minute periods. The mode of AUC calculation, performed with the use of planimetry, is presented in Fig. 1. The data were expressed in means \pm S.D., $n=4$. Statistical analysis was performed with 

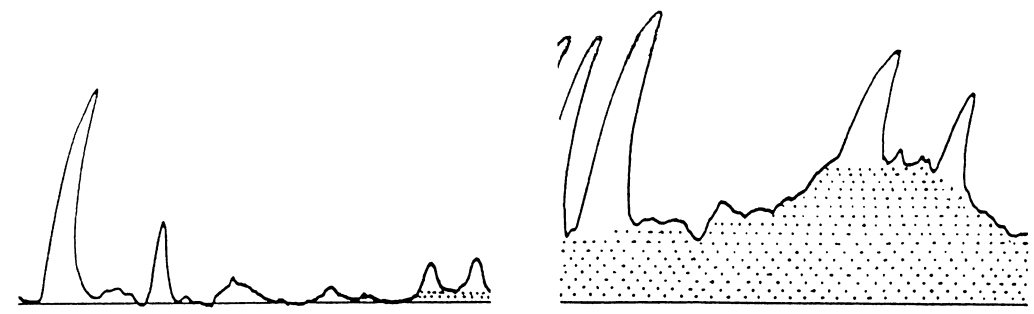

Fig. 1. Illustration of assessment method of phasic and tonic contractile components in the ovine duodenum. Left: $30-$ $\mathrm{sec}$ fragment of the duodenal mechanical control recording during phase $2 \mathrm{~b}$ MMC just before cerulein administration in non- fasted sheep. Right: 30-sec fragment of the duodenal mechanical recording just after cerulein administration at the dose of $100 \mathrm{ng} / \mathrm{kg}$ during the same experiment. Phasic and tonic components were measured as area under the curve (AUC), above the baseline (straight solid line) Open areas: phasic component; dotted areas: tonic component. Baseline was depicted as the average (streightened) level of control recording. $\mathrm{T}$ - time in sec. $\mathrm{C}$ - calibration $50 \mu \mathrm{V}$ for the electrodes and $5 \mathrm{~g}$ for the strain gauge force transducer. For further explanations see section Materials and Methods.

the use of variance analysis (ANOVA) and Student $t$-test for paired values (Snedecor and Cochran 1971), and $P<0.05$ was considered as the lowest degree of statistical significance.

\section{Results}

Mechanical activity of the duodenum was reflected by its electrical activity and it was well correlated with the electrical activity of the adjacent regions studied. Administration of CCK-OP and cerulein inhibited the MR in duodenal bulb and in proximal duodenum while the MR in distal part of the duodenum was intensified (Fig. 2). In non-fasted sheep the clear
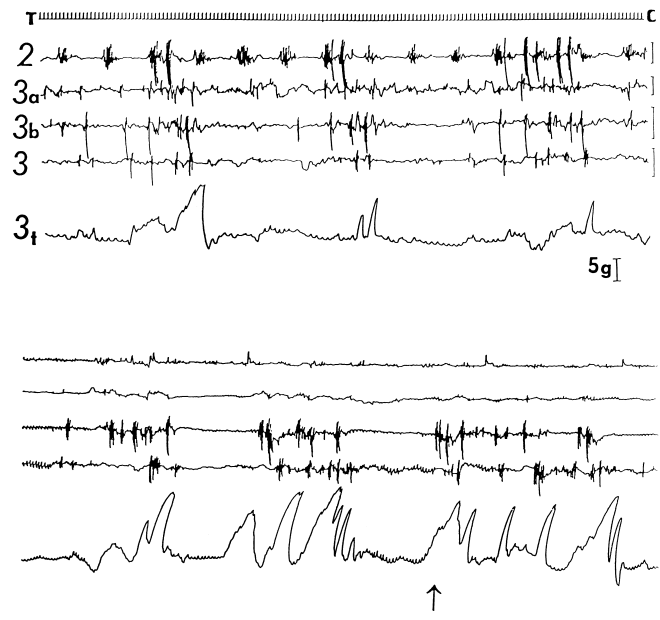

Fig. 2. Two fragments of 5.5 minute duodenal recording in non-fasted sheep before (upper panel) and after (lower panel) the maximal dose of cerulein administration during phase $2 \mathrm{~b}$ MMC. Note the stimulation of the duodenal motility and preservation of the MR pattern, as well as its inhibition in upper duodenum including the duodenal bulb. Note also the enhancement of both phasic and tonic components in mechanical recording. Arrow indicates $6 \mathrm{~min}$ after the termination of the hormonal peptide injection. Electrodes: 2 - duodenal bulb, $3 \mathrm{a}$ and $3 \mathrm{~b}$ additional electrodes in proximal-mid duodenum, $3_{\mathrm{t}}$ - mechanical recording from the strain gauge force transducer localized near the electrode 3 inserted in distal duodenum. For further explanations see Fig. 1 and section Materials and Methods.

phasic and tonic components were identified in the duodenum (Table 1). Both CCK-OP and cerulein affected these components significantly and in a dose-response manner. Significant effects were observed especially after two higher doses of the hormone. However, the effect of the hormone on the tonic component was greater than upon the phasic component. The applied doses of CCK-OP exerted slightly stronger effects than those of cerulein. That is why, unlike cerulein, the effect of the lowest dose of CCK-OP on the tonic component was also significant. When phasic and tonic components were summarized, the character of CCK effect was additive. In fasted sheep the effect of CCK peptides was roughly similar to that 
in non-fasted sheep (Table 2). Significant alterations either in phasic or in tonic components following CCK administration were also observed.

Table 1. Phasic and tonic components of the duodenal contractions in non-fasted sheep before and after cerulein and cholecystokinin octapeptide (CCK-OP) administration during phase $2 \mathrm{~b}$ MMC

\begin{tabular}{|c|c|c|c|c|c|c|}
\hline & \multicolumn{3}{|c|}{ Cerulein } & \multicolumn{3}{|c|}{$\mathrm{CCK}-\mathrm{OP}$} \\
\hline & $1 \mathrm{ng} / \mathrm{kg}$ & $10 \mathrm{ng} / \mathrm{kg}$ & $100 \mathrm{ng} / \mathrm{kg}$ & $20 \mathrm{ng} / \mathrm{kg}$ & $200 \mathrm{ng} / \mathrm{kg}$ & $2000 \mathrm{ng} / \mathrm{kg}$ \\
\hline \multicolumn{7}{|l|}{ Phasic component } \\
\hline \multirow{2}{*}{$\begin{array}{r}\text { - control: mean } \\
\pm \text { S.D. }\end{array}$} & 15.3 & 12.9 & 14.5 & 13.6 & 15.1 & 14.6 \\
\hline & 5.1 & 4.7 & 1.0 & 6.0 & 3.3 & 1.6 \\
\hline \multirow{2}{*}{$\begin{array}{r}\text { - CCK: mean } \\
\pm \text { S.D. }\end{array}$} & 16.0 & 17.8 & $48.5^{5 * *}$ & 17.8 & $23.0^{*}$ & $34.0^{* * *}$ \\
\hline & 3.2 & 3.6 & 15.8 & 3.1 & 5.4 & 6.4 \\
\hline \multirow{3}{*}{$\begin{array}{l}\text { Tonic component } \\
- \text { control: mean } \\
\pm \text { S.D. }\end{array}$} & & & & & & \\
\hline & 4.5 & 6.8 & 4.8 & 6.5 & 5.5 & 6.1 \\
\hline & 1.3 & 3.1 & 2.8 & 2.6 & 4.5 & 3.1 \\
\hline \multirow{2}{*}{$\begin{array}{r}\text { - CCK: mean } \\
\pm \text { S.D. }\end{array}$} & 7.8 & $19.5^{*}$ & $71.0 * * *$ & $12.3^{*}$ & $26.8^{* * *}$ & $41.0^{* * *}$ \\
\hline & 3.5 & 10.3 & 17.1 & 3.8 & 10.3 & 11.2 \\
\hline \multicolumn{7}{|l|}{ Total } \\
\hline \multirow{2}{*}{$\begin{array}{r}\text { - control: mean } \\
\pm \text { S.D. }\end{array}$} & 19.9 & 19.8 & 19.7 & 20.6 & 20.9 & 21.4 \\
\hline & 4.0 & 7.3 & 3.3 & 7.8 & 7.8 & 4.6 \\
\hline \multirow{2}{*}{$\begin{array}{c}\text { - CCK: mean } \\
\pm \text { S.D. }\end{array}$} & 24.7 & $37.6^{*}$ & $119.7 * * *$ & 30.4 & $49.9 * * *$ & $75.3^{* * *}$ \\
\hline & 5.8 & 10.2 & 32.3 & 6.8 & 12.3 & 17.4 \\
\hline
\end{tabular}

Phasic component - sum of phasic contractions calculated during 5 min (for lowest cerulein or CCK-OP doses), $10 \mathrm{~min}$ (for moderate dose of CCK peptides) and $20 \mathrm{~min}$ (for highest dose of CCK peptides) recalculated for $1 \mathrm{~min}$ and expressed in $\mathrm{g}$. sec per min. Tonic component - sum of tonic contractions calculated and expressed as phasic component. Total - sum of all contractions, $\mathrm{n}=4$, statistical significances: $* p<0.05, * * p<0.01, * * * p<0.001$ vs. relevant control value. Other explanations as in the section Materials and Methods.

Table 2. Phasic and tonic components of duodenal contractions in fasted sheep before and after CCK-OP and cerulein administration during phase $2 \mathrm{~b} \mathrm{MMC}$

\begin{tabular}{|c|c|c|c|c|c|c|}
\hline & \multicolumn{3}{|c|}{ Cerulein } & \multicolumn{3}{|c|}{$\mathrm{CCK}-\mathrm{OP}$} \\
\hline & $1 \mathrm{ng} / \mathrm{kg}$ & $10 \mathrm{ng} / \mathrm{kg}$ & $100 \mathrm{ng} / \mathrm{kg}$ & $20 \mathrm{ng} / \mathrm{kg}$ & $200 \mathrm{ng} / \mathrm{kg}$ & $2000 \mathrm{ng} / \mathrm{kg}$ \\
\hline \multicolumn{7}{|l|}{ Phasic component } \\
\hline \multirow{2}{*}{$\begin{array}{r}\text { - control: mean } \\
\pm \text { S.D. }\end{array}$} & 11.4 & 10.6 & 12.3 & 11.7 & 12.6 & 11.8 \\
\hline & 4.0 & 3.2 & 2.7 & 3.8 & 3.5 & 2.9 \\
\hline \multirow{2}{*}{$\begin{array}{r}\text { - CCK: mean } \\
\pm \text { S.D. }\end{array}$} & 12.6 & $14.8^{*}$ & $27.6^{* * *}$ & 14.4 & $19.5^{*}$ & $26.6^{* * *}$ \\
\hline & 3.4 & 2.8 & 5.4 & 3.7 & 4.2 & 6.8 \\
\hline \multicolumn{7}{|l|}{ Tonic component } \\
\hline $\begin{array}{r}\text { - control: mean } \\
\pm \text { S.D. }\end{array}$ & 2.3 & 1.7 & 2.0 & 2.9 & 1.6 & 3.4 \\
\hline \multirow{2}{*}{$\begin{array}{r}\text { - CCK: mean } \\
\pm \text { S.D. }\end{array}$} & 6.6 & $16.4^{* * *}$ & $37.6^{* * *}$ & 10.6 & $17.8^{* * *}$ & $31.7^{* * *}$ \\
\hline & 1.8 & 5.8 & 12.5 & 2.7 & 4.8 & 14.4 \\
\hline \multicolumn{7}{|l|}{ Total } \\
\hline \multirow{2}{*}{$\begin{array}{r}- \text { control: mean } \\
\pm \text { S.D. }\end{array}$} & 16.5 & 15.8 & 8.3 & 17.9 & 17.5 & 17.2 \\
\hline & 4.1 & 2.6 & 2.9 & 3.3 & 3.1 & 4.3 \\
\hline \multirow{2}{*}{$\begin{array}{c}\text { - CCK: mean } \\
\pm \text { S.D. }\end{array}$} & 19.3 & $31.7^{* * *}$ & $64.8^{* * *}$ & $24.8^{*}$ & $37.7^{* * *}$ & $57.8^{* * *}$ \\
\hline & 3.7 & 5.4 & 14.7 & 4.4 & 5.9 & 16.5 \\
\hline
\end{tabular}

Explanations as in Table 1. 
When phasic and tonic components were assessed separately for MR contractions of non-fasted sheep, it was revealed that only two higher doses of CCK-OP and the highest dose of cerulein enhanced AUC of the phasic component of MR while the values of the tonic component were significantly affected in response to both higher doses of cerulein and to all doses of CCK-OP applied (Table 3). Cerulein increased AUC of the phasic component and two higher doses of the peptide increased the tonic component of MR in the duodenum. The effect of CCK peptides on phasic plus tonic components of MR was near the sum of the effects on both these components.

Table 3. Phasic and tonic components of MR-like duodenal contractions in non-fasted sheep before and after $\mathrm{CCK}-\mathrm{OP}$ and cerulein administration during phase $2 \mathrm{~b} \mathrm{MMC}$

\begin{tabular}{|c|c|c|c|c|c|c|}
\hline & \multicolumn{3}{|c|}{ Cerulein } & \multicolumn{3}{|c|}{$\mathrm{C} \mathrm{CK}-\mathrm{OP}$} \\
\hline & $1 \mathrm{ng} / \mathrm{kg}$ & $10 \mathrm{ng} / \mathrm{kg}$ & $100 \mathrm{ng} / \mathrm{kg}$ & $20 \mathrm{ng} / \mathrm{kg}$ & $200 \mathrm{ng} / \mathrm{kg}$ & $2000 \mathrm{ng} / \mathrm{kg}$ \\
\hline \multirow{2}{*}{$\begin{array}{r}\text { Phasic component } \\
\text { - control: mean } \\
\pm \text { S.D. }\end{array}$} & 11.0 & 8.9 & 11.1 & 8.7 & 10.6 & 11.3 \\
\hline & 3.8 & 2.8 & 0.8 & 3.2 & 1.8 & 1.1 \\
\hline \multirow{2}{*}{$\begin{array}{r}\text { - CCK: mean } \\
\pm \text { S.D. }\end{array}$} & 10.4 & 12.6 & $19.6^{*}$ & 13.4 & $15.3 *$ & $17.4^{*}$ \\
\hline & 2.7 & 2.4 & 7.5 & 2.3 & 3.1 & 4.2 \\
\hline \multirow{2}{*}{$\begin{array}{l}\text { Tonic component } \\
\begin{array}{r}\text { - control: mean } \\
\pm \text { S.D. }\end{array}\end{array}$} & 3.7 & 5.2 & 3.8 & 4.8 & 4.7 & 5.3 \\
\hline & 1.1 & 2.6 & 2.2 & 1.9 & 3.0 & 2.5 \\
\hline \multirow{2}{*}{$\begin{array}{r}\text { - CCK: mean } \\
\\
\pm \text { S.D. }\end{array}$} & 5.7 & $12.2 *$ & $15.8 * * *$ & $8.1^{*}$ & $11.3^{*}$ & $14.9 * *$ \\
\hline & 2.6 & 5.4 & 4.3 & 2.4 & 3.8 & 4.6 \\
\hline \multirow{3}{*}{$\begin{array}{l}\text { Total } \\
\qquad \begin{aligned} \\
\text { - control: mean } \\
\pm \text { S.D. }\end{aligned}\end{array}$} & & & & & & \\
\hline & 15.2 & 14.0 & 15.2 & 13.7 & 16.2 & 16.5 \\
\hline & 2.6 & 2.3 & 1.6 & 3.8 & 2.6 & 2.4 \\
\hline \multirow{2}{*}{$\begin{aligned} \text { - CCK: } & \text { mean } \\
& \pm \text { S.D. }\end{aligned}$} & 16.3 & $25.3 * * *$ & $35.1 * * *$ & $21.3 *$ & $26.2^{*}$ & $33.1 * * *$ \\
\hline & 2.4 & 4.1 & 6.1 & 2.0 & 4.3 & 5.7 \\
\hline
\end{tabular}

Explanations as in Table 1.

Table 4. Phasic and tonic components of MR-like duodenal contractions in fasted sheep before and after $\mathrm{CCK}-\mathrm{OP}$ and cerulein administration during phase $2 \mathrm{~b} \mathrm{MMC}$

\begin{tabular}{|c|c|c|c|c|c|c|}
\hline & \multicolumn{3}{|c|}{ Cerule in } & \multicolumn{3}{|c|}{$\mathrm{C} \mathrm{CK}-\mathrm{OP}$} \\
\hline & $1 \mathrm{ng} / \mathrm{kg}$ & $10 \mathrm{ng} / \mathrm{kg}$ & $100 \mathrm{ng} / \mathrm{kg}$ & $20 \mathrm{ng} / \mathrm{kg}$ & $200 \mathrm{ng} / \mathrm{kg}$ & $2000 \mathrm{ng} / \mathrm{kg}$ \\
\hline \multirow{2}{*}{$\begin{array}{r}\text { Phasic component } \\
\text { - control: mean } \\
\pm \text { S.D. }\end{array}$} & 6.4 & 6.8 & 7.2 & 5.9 & 6.3 & 6.8 \\
\hline & 2.3 & 2.4 & 2.1 & 1.7 & 2.4 & 2.6 \\
\hline \multirow{2}{*}{$\begin{array}{r}\text { - CCK: mean } \\
\pm \text { S.D. }\end{array}$} & 6.7 & 7.9 & $12.8 *$ & 7.1 & 10.6 & $18.7 * *$ \\
\hline & 2.2 & 3.1 & 3.4 & 3.3 & 4.1 & 6.2 \\
\hline \multirow{2}{*}{$\begin{array}{l}\text { Tonic component } \\
\begin{array}{r}\text { - control: mean } \\
\pm \text { S.D. }\end{array}\end{array}$} & 2.3 & 3.2 & 2.7 & 2.6 & 2.9 & 3.0 \\
\hline & 0.8 & 1.0 & 1.1 & 0.9 & 1.3 & 1.2 \\
\hline \multirow{2}{*}{$\begin{array}{r}- \text { CCK: mean } \\
\pm \text { S.D. }\end{array}$} & 3.0 & 5.6 & $11.4 * * *$ & 4.2 & $8.7 * *$ & $16.9 * * *$ \\
\hline & 0.7 & 1.8 & 3.7 & 1.6 & 2.4 & 5.4 \\
\hline \multirow{2}{*}{$\begin{array}{l}\text { Total } \\
\qquad \begin{array}{r}\text { - control: mean } \\
\pm \text { S.D. }\end{array}\end{array}$} & 8.5 & 10.2 & 10.1 & 8.6 & 9.0 & 10.2 \\
\hline & 1.8 & 1.9 & 2.0 & 1.8 & 3.2 & 3.1 \\
\hline \multirow{2}{*}{$\begin{array}{r}- \text { CCK: mean } \\
\text { tS.D. }\end{array}$} & 9.8 & 13.8 & $24.0 * * *$ & 11.8 & $19.7 * * *$ & $35.1 * * *$ \\
\hline & 2.4 & 2.7 & 4.4 & 3.0 & 4.4 & 7.2 \\
\hline
\end{tabular}

Explanations as in Table 1. 
In fasted sheep the effects of CCK peptides used in the study on phasic and tonic components of MR were smaller than in non-fasted animals but still significantly greater than the control values (Table 4). Cerulein and CCK-OP at the highest doses stimulated phasic AUC significantly. Both higher CCK-OP doses applied here increased the tonic component but the effect of cerulein was significant following its highest dose. When the effects of CCK peptides on both phasic and tonic components were added, both higher doses of CCK-OP exerted significant effect while only the highest dose of cerulein was effective.

\section{Discussion}

Both CCK peptides significantly altered the myoelectric and motor responses examined in ovine duodenum. CCK-OP and cerulein are known to stimulate small-intestinal motility reversing the interdigestive to a digestive-like pattern (W alsh 1994). In sheep, the reported effect of CCK on duodenal spike bursts was not marked (Bueno and Praddaude 1979) although more recent study provided different results (Romański 2004). The character of duodenal stimulation was different from the feeding pattern that is more irregular and where MR is interposed between more numerous spike bursts (Romański 2002). The duodenal pattern observed after administration of CCK was more rhythmic and contained more regular series of spike bursts than that observed after feeding. The latter were organized mostly in MR-like fashion. Therefore, CCK stimulates the ovine duodenum by increasing the number of the spike bursts in MR-like pattern. Apparently, it cooperates with cholinergic system in this action (Romański 2002).

It has already been reported that MR exhibits a propulsive character (Summers and Dusdieker 1981), thus the question arises to what extent the increase in duodenal propulsion accompanies MR occurrence. During the manometric studies, clearly propagated MR in the small intestine was described in humans (Ducrotte et al. 1991; Wilmer et al. 1998). As it can be concluded from these studies, the propagated contractions can be responsible also for propulsion of intestinal digesta. However, this cannot serve as a direct evidence for the propulsive character of MR.

The effect of CCK on MR arrival in the duodenal bulb as compared to that observed in the distal duodenum was clearly inhibitory. The character of this response resembles the effect of CCK on forestomach motility in which the hormone reduces the frequency rather than the amplitude of contractions (Ruckebusch 1985). Since the inhibitory effect of CCK on gastric function is considered physiological (Walsh 1994), the question is whether its similar influence on duodenal bulb motility can also be regarded as the physiological action of this hormone. Thus, the mean dose of the CCK-OP used here can be considered to remain within the range of physiological CCK doses for inhibition of duodenal motility (Romański 2005). Administration of CCK-OP in 20-fold higher amounts than of cerulein, considered to be of similar potency (Romański 2004), evoked stronger effect on MR incidence as compared with the effect of cerulein. Ruckebusch and Soldani (1985) found that 10-fold lower cerulein dose than CCK-OP evoked even stronger gallbladder contractile response. These doses were similar to those used in the present study. It has been well established that $1 \mathrm{ng} / \mathrm{kg}$ of cerulein is the minimal effective dose (Fau stini et al. 1973) whereas $100 \mathrm{ng} / \mathrm{kg}$ of CCK-OP was also effective (B u e no and Prad d a u de 1979). It seems likely that equipotent doses of cerulein and CCK-OP remain between $1: 8$-10 and $1: 15$ depending on the site of action and parameters examined.

The duodenal stimulatory response to CCK comprised not only the phasic but also the tonic component. There is rather no doubt that CCK stimulates phasic contractions in the small intestine (Bueno and Praddaude 1979; Giuliani et al. 1990; Mukhopadhy ay et al. 1977; Romański 2002) although there are some reports showing that duodenum did not respond significantly to CCK administration especially when the studies were performed 
in fasted animals (Wingate et al. 1978). Its action can be also inhibitory as studied on isolated rat duodenum (Martins et al. 2006). The effects of CCK on tonic contractions within the gastrointestinal tract have not been extensively examined and the effect of CCK on the tonic component in the small bowel in sheep is unknown. The widely described stimulatory action of CCK on gallbladder contraction was firstly recognized as the ability of the hormone to affect tonic contractions (Walsh 1994). However, some other reports indicate that CCK can stimulate tonic motility in the stomach, pylorus and ruminal muscle (Fras er et al. 1993; Lüdtke et al. 1988; Onaga et al. 1989) as well as in the large intestine (Coffin et al. 1999) in various animal species including ruminants. Other reports suggest that CCK and related peptides increase tonic contractions in the small bowel of monogastrics (Dollinger et al. 1975; Niederau and Karau s 1991; Stacher et al. 1984; Stewart and Burks 1977) but other authors did not make this observation (Anuras and Cooke 1978; Gutiérez et al. 1974). It is possible that this effect could be evoked by excitation of tension receptors by CCK (Cottrell and Reynolds 1994). Thus, the stimulation of the tonic component of MR in the ovine small bowel by CCK is a new finding, although such effect can be expected.

The action of CCK observed in the present study was composed. CCK exerts its motor actions through at least two distinct CCK receptor subtypes, i.e. CCK 1 (CCK-A) and CCK 2 (CCK-B/gastrin) receptors and the heterogeneity of CCK 1 receptor subtype was suggested (Miyasaka and Funakoshi 2003; Morton et al. 2002). CCK receptors are also present in ruminants (Kania et al. 2002; Le Drean et al. 1999; Onaga et al. 1997; Yonekura et al. 2002). These receptors are localized either on the smooth muscle cells or within central and peripheral nervous system structures controlling gastrointestinal motility. Neuronal action of CCK on gastrointestinal motility is indirect and can be further mediated by other receptors including cholinergic and opioid receptors (Kania et al. 1999; Katchinski et al. 1996). CCK can also exert its action through the regulation of the release of other hormones like glucagon, insulin or somatostatin (Mineo et al. 1994; Zavros and Shulkes 1997; Zavros et al. 1998). However, the precise mechanism of CCK action on ovine gastrointestinal motility remains highly unrecognized.

Finally, it can be concluded that CCK markedly influences the duodenal motility and MR in sheep and these effects comprise both phasic and tonic components. Initiation of the tonic component of MR may shorten the time lag between stimulus and muscle reaction and perhaps also increase the propulsive efficacy of MR.

\section{Účinek cholecystokininu-oktapeptidu a ceruleinu na motilitu a tonus ovčího dudodena ve vztahu k elektrickému rytmu}

Cholecystokinin (CCK) může ovlivnit motilitu a minutový elektrický rytmus (MR) ovčího duodena, ale jeho účinek na tenzi zůstává nejasný. Tudíž cílem této studie bylo zjistit jestli má tento hormon signifikantní vliv na motilitu a tonus v rámci celkové duodenální motorické aktivity a motilitu a tonus v rámci MR. U čtyř ovcí byly v průběhu $2 \mathrm{~b}$ fáze migrujícího myoelektrického komplexu snímány chemické a elektrické aktivity duodena před a po pomalé intravenózní aplikaci cholecystokininu oktapeptidu (CCK-OP, v dávce 20, 200 a $2000 \mathrm{ng} \cdot \mathrm{kg}^{-1}$ živé váhy) a ceruleinu (v dávce 1 , 10 a $100 \mathrm{ng} \cdot \mathrm{kg}^{-1}$ živé váhy). Během 5-20 min časových úseků byly pod křivkou kontraktilní aktivity měřeny úseky motility, tonu a celkové motorické aktivity pro celou křivku a zvlášt pro aktivitu spojenou s MR. Bylo zjištěno, že oba CCK peptidy zvyšují motilitu i tonus v rámci celkové duodenální motorické aktivity a stejně tak i motilitu a tonus v rámci duodenálního MR. Vliv CCK peptidů na tonus byl větší než jejich vliv na motilitu. Tyto jevy byly stejné jak u nažraných tak u lačněních zvírat. CCK-OP vyvolal poněkud větší změny než cerulein. Účinky těchto CCK peptidů na motilitu a tonus v rámci MR byly obdobné. Závěrem je, že CCK-OP a cerulein stimulují 
u ovcí jak motilitu tak tonus v rámci celkové duodenální motorické aktivity a motilitu a tonus ve vztahu $\mathrm{k}$ MR.

\section{References}

ANURAS S, COOKE AR 1978: Effects of some gastrointestinal hormones on two muscle layers of the duodenum. Am J Physiol 234: E60-E63

BEHAR J, CORAZZIARI E, GUCLRUD M, HOGAN W, SHERMAN S, TOOULI J 2006: Functional gallbladder and sphincter of Oddi disorders. Gastroenterology 130: 1498-1509

BUENO L, PRADDAUDE F 1979: Electrical activity of the gallbladder and biliary tract in sheep and its relationships with antral and duodenal motility. Ann Biol Anim Biochim Biophys 19: 1109-1121

CHUA AS, KEELING PW 2006: Cholecystokinin hyperresponsiveness in functional dyspepsia. World J Gastroenterol 12: 2688-2693

CODE CF, MARLETT JA 1975: The interdigestive myoelectric complex of the stomach and small bowel of dogs. J Physiol - London 246: 289-309

COFFIN B, FOSSATI S, FLOURIÉ B, LÉMANN M, JOUET P, FRANCHISSEUR C, JIAN R, RAMBAUD JC 1999: Regional effects of cholecystokinin octapeptide on colonic phasic and tonic motility in healthy humans. Am J Physiol 276: G767-G772

COTTRELL DF, REYNOLDS GW 1994: Electrophysiological characteristics of tension receptors in the abomasal antrum of sheep. Vet Res Commun 18: 225-238

DENT J, DODDS WJ, SEKIGUCHI T, HOGAN WJ, ARNDORFER RC 1983: Interdigestive phasic contractions of the human lower esophageal sphincter. Gastroenterology 84: 453-460

DI FRANCESCO V, ZAMBONI M, DIOLI A, ZOICO E, MAZZALI G, OMIZZOLO F, BISSOLI L, SOLERTE SB, BENINI L, BOSELLO O 2005: Delayed postprandial gastric emptying and impaired gallbladder contraction together with elevated cholecystokinin and peptide YY serum levels sustain satiety and inhibit hunger in healthy elderly persons. J Gerontol A Biol Sci Med 60: 1581-1585

DOLLINGER HC, BERZ R, RAPTIS S, VON UEXKÜLL T, GOEBELL H 1975: Effects of secretin and cholecystokinin on motor activity of human jejunum. Digestion 12: 9-16

DUCROTTE P, PEILLON C, GUILLEMOT F, TESTART J, DENIS P 1991: Could recurrent cholangitis after Roux-en-Y hepaticojejunostomy be explained by motor intestinal anomalies? Am J Gastroenterol 86: 1255-1258

FAUSTINI R, BERETTA C, CHELI R, DE GRESTI A 1973: Some effects of caerulein on the motility of sheep forestomach and gall bladder. Pharmacol Res Commun 5: 383-387

FLECKENSTEIN P, BUENO L, FIORAMONTI J, RUCKEBUSCH Y 1982: Minute rhythm of electrical spike bursts of the small intestine in different species. Am J Physiol 242: G654-G659

FRASER R, FONE D, HOROWITZ M, DENT J 1993: Cholecystokinin octapeptide stimulates phasic and tonic pyloric motility in healthy humans. Gut 34: 33-37

GIULIANI S, LIPPE IT, MAGGI CA, MELI A 1990: Dual effects of cholecystokinin-octapeptide on duodenal motility of urethane-anesthetized rats. J Pharmacol Exp Ther 252: 1312-1317

GUTIÉREZ G, CHEY WY, DINOSO VP 1974: Actions of cholecystokinin and secretin on the motor activity of the small intestine in man. Gastroenterology 67: 35-41

HARVATINE KJ, ALLEN MS 2005: The effect of production level on feed intake, milk yield, and endocrine responses to two fatty acid supplements in lactating cows. J Dairy Sci 88: 4018-4027

JENSEN RT 2002: Involvement of cholecystokinin/gastrin-related peptides and their receptors in clinical gastrointestinal disorders. Pharmacol Toxicol 91: 333-350

KANIA BF, BRIKAS P, BUÉNO L, FIORAMONTI J, ZAREMBA-RUTKOWSKA M 1999: The evaluation of the role of CCK in the opioid modulation of the motility of the gastrointestinal tract in sheep. J Vet Pharmacol Ther 22: 153-160

KANIA BF, KANIA K, ROMANOWICZ K, TOMASZEWSKA D, SUTIAK V, WROŃSKA-FORTUNA D 2006: Centrally administered PD 140.548 N-methyl-D-glucamine prevents the autonomic responses to duodenal pain in sheep. Res Vet Sci 81: 109-118

KANIA BF, MATCZUK J, ROMANOWICZ K, BUENO L, FIORAMONTI J, KANIA K 2002: CCK1 central receptor antagonist prevented the intestinal stress symptoms in sheep. Pol J Vet Sci 5: 35-42

KATCHINSKI M, SCHIRRA J, BEGLINER C, LANGBEIN S, WANK U, D'AMATO M, ARNOLD R 1996: Intestinal phase of human antro-pyloro-duodenal motility: cholinergic and CCK-mediated regulation. Eur J Clin Invest 26: $574-583$

LE DREAN G, LE HUEROU-LURON I, GESTIN M, DESBOIS C, ROME V, BERNARD C, DUFRESNE M, MORODER L, GULLY D, CHAYVIALLE JA, FOURMY D, GUILLOTEAU P 1999: Exogenous CCK and gastrin stimulate pancreatic exocrine secretion via CCK-A but also via CCK-B/gastrin receptors in the calf. Pflüg Arch 438: 86- 93

LÜDTKE FE, GOLENHOFEN K, KÖHNE C 1988: Direct effects of cholecystokinin on human gastric motility. Digestion 39: 210- 218

MALBERT CH, RUCKEBUSCH Y 1989: Vagal influence on the phasic and tonic components of the motility of the ovine stomach and gastroduodenal area. J Gastrointest Motil 1: 15-20 
MARTINS SR, OLIVEIRA RB, BALLEJO G 2006: Activation of neural cholecystokinin-1 receptors induces relaxation of the isolated rat duodenum which is reduced by nitric oxide synthase inhibitors. Braz $\mathrm{J}$ Med Biol Res 39: 271-275

MINEO H, IWAKI N, ONAGA T, KATO S 1994: Effects of intravenous infusions of cholecystokinin-8 and pentagastrin on plasma concentrations of insulin and glucagon in sheep. Res Vet Sci 56: 298-302

MIYASAKA K, FUNAKOSHI A 2003: Cholecystokinin and cholecystokinin receptors. J Gastroenterol 38: 1-13

MORTON MF, HARPER EA, TAVARES IA, SHANKLEY NP 2002: Pharmacological evidence for putative CCK(1) receptor heterogeneity in human colon smooth muscle. Brit J Pharmacol 136: 873-882

MUKHOPADHYAY AK, THOR PJ, COPELAND EM, JOHNSON LR, WEISBRODT NW 1977: Effect of cholecystokinin on myoelectric activity of small bowel of the dog. Am J Physiol 232: E44-E47

NIEDERAU C, KARAUS M 1991: Effects of CCK receptor blockade on intestinal motor activity in conscious dogs. Am J Physiol 260: G315-G324

ONAGA T, KATO S, MINEO H. USHIJIMA J 1989: Effect of cholecystokinin octapeptide on contraction of bovine ruminal muscle. Asian-Austral J Anim Sci 2: 165-166

ONAGA T, MINEO H, KATO S 1997: Effect of L364718 on interdigestive pancreatic exocrine secretion and gastroduodenal motility in conscious sheep. Regul Peptides 68: 139-146

RAKOVSKA A, MILENOV K, YANEV S 1986: Mode of action of cholecystokinin octapeptide on smooth muscles of stomach, ileum and gall bladder. Method Find Exp Clin Pharmacol 8: 697-703

ROMAŃSKI KW 2002: Characteristics and cholinergic control of the 'minute rhythm' in ovine antrum, small bowel and gallbladder. J Vet Med A 49: 313-320

ROMAŃSKI KW 2004: Ovine model for clear-cut study on the role of cholecystokininin antral, small intestinal and gallbladder motility. Pol J Pharmacol 56: 247-256

ROMAŃSKI KW 2005: Cholecystokinin as a physiological regulator of abomasal motility in sheep. Med Wet 61: 1312-1316 (in Polish)

ROMAŃSKI KW, KURYSZKO J 1995: The influence of chronic electrode implantation upon the myoelectric activity and histology of the stomach, small intestine and gallbladder in sheep. Arch Vet Pol 35: 127-135

RUCKEBUSCH Y 1985: Regulation of reticuloruminal motor activity and cyclical activity of the gastroduodenal junction. In: OOMS LAA, DEGRYSE AD, MARSBOOM R: The Ruminant Stomach. Proceedings of an international Workshop, Antwerp: Published under the auspices of the Janssen Research Foundation, pp. 19-51

RUCKEBUSCH Y, SOLDANI G 1985: Gallbladder motility in sheep: effects of cholecystokinin and related peptides. J Vet Pharmacol Ther 8: 263-269

SCHANG JC, KELLY KA 1981: Inhibition of canine interdigestive proximal gastric motility by cholecystokinin octapeptide. Am J Physiol 240: G217-G220

SNEDECOR GW, COCHRAN WG 1971: Statistical Methods. The Iowa State University Press, Ames, 575 p.

STACHER G, STEINRINGER H, SCHMIERER G, SCHNEIDER C, WINKLEHNER S, MITTELBACH G, DEPAOLIS C, PRAGA C 1984: Dose-dependent effects of ceruletide on jejunal motor activity and on experimentally induced pain in healthy humans. In: ROMAN C.: Gastrointestinal Motility, MTP Press Limited, Lancaster, pp. 355-356.

STEWART JJ, BURKS TF 1977: Actions of cholecystokinin octapeptide on smooth muscle of isolated dog intestine. Am J Physiol 232: E306-E310

SUMMERS RW, DUSDIEKER NS 1981: Patterns of spike bursts spread and flow in the canine small intestine. Gastroenterology 81: 742-750

WALSH JH 1994: Gastrointestinal hormones. In: JOHNSON LR: Physiology of the Gastrointestinal Tract, Raven Press, New York, pp. 1-128

WILMER A, VAN CUTSEM E, ANDRIOLI A, TACK J, COREMANS G, JANSSENS J, 1998: Ambulatory gastrojejunal manometry in severe motility-like dyspepsia: lack of correlation between dysmotility, symptoms, and gastric emptying. Gut 42: 235-242

WINGATE DL, THOMPSON HH, PEARCE EA, DAND A 1978: The effects of exogenous cholecystokinin and pentagastrin on myoelectrical activity in the small intestine of the conscious fasted dog. In: DUTHIE HL: Gastrointestinal Motility in Health and Disease, MTP Press, Lancaster, pp. 47- 58

YONEKURA S, KITADE K, FURUKAWA G, TAKAHASHI K, KATSUMATA N, KATOH K, OBARA Y 2002 : Effects of aging and weaning on mRNA expression of leptin and CCK receptors in the calf rumen and abomasum. Domest Anim Endocrin 22: 25-35

ZAVROS Y, FLEMING WR, HARDY KJ, SHULKES A 1998: Regulation of fundic and antral somatostatin secretion by CCK and gastrin. Am J Physiol 274: G742-G750

ZAVROS Y, SHULKES A 1997: Cholecystokinin (CCK) regulates somatostatin secretion through both the CCKA and CCK- B/gastrin receptors in sheep. J Physiol - London 505(3): 811-821 